\title{
Support and implementation of the government program in the agricultural sector for business entities subjects on the example of the Republic of Bashkortostan
}

\author{
Lyuza Bayguzina ${ }^{l}$, Guzaliya Galimova ${ }^{l}$, Elvira Nurdavlyatova $^{l}$, and Larisa Ponomareva ${ }^{l}$ \\ ${ }^{1}$ Department of Finance and taxation, Bashkir State University, 450076, Zaki Validi st., Ufa, Russia
}

\begin{abstract}
The scientific article discusses the implementation of the state program "Development of Agriculture andregulation of agricultural products, raw materials and food markets in the RepublicBashkortostan", which aims to ensure the implementation of planned production valuescommodity production volumes of the main types of products. Effectiveness of the implementation of measuresgovernment program is largely determined by the volume of involvement in the Republic of Bashkortostanfederal funds.In this regard, the importance of the work of signing agreements betweenThe Ministry of Agriculture of the Russian Federation and the Government of the Republic of Bashkortostan onallocation of federal funds to the republic.At the present stage, global changes are taking place both in the global economy and in the regionallevel.Therefore, there is a need for innovative and costeffectiveproduction methods. One of the directions of public policyin the agro-industrial complex is the support of innovatively active enterprises, farmersfarms that can solve the main economic problems and the country's recovery from the crisis andensure sustainable innovative development of the economy.
\end{abstract}

\section{Methodology}

Working methodology is composed of the application of general and special scientific analysis methods - system analysis, applied to various socio-economic subsystems.

\section{Results}

The authors pay attention to the directions of agricultural development in modern conditions, identify problems in this area, including at the regional level. The authors analyze the indicators of the physical volume of agricultural production by categories of farms, the volume of state support for agricultural enterprises, the direction of the supported projects of beginning farmers.

\section{Conclusion}


At the current economic stage, agriculture is one of the main economic activities of the Republic of Bashkortostan. The presented statistics indicate the effectiveness of the region, which, in turn, has a significant impact on the economic and social condition of the region.It should be noted that at present, the positive dynamics of agricultural production has been achieved by expanding the scale of production to increase the number of livestock and cattle breeding due to the additional placement of up to 300 thousand heads ofcattle. For this was been taking into account the area of forage crops, natural pastures and empty livestock complexes.

At the same time, special attention is paid to increasing the role and potential of small farms in the production of high-quality beef, increasing the number of beef cattle and crossing animals based on the development of family farms based on peasant farms. This would significantly contribute to the development of abandoned and degraded hayfields and pastures, a partial reduction of unemployment, strengthening in the demographic situation in rural areas and an improvement in the quality of life of the rural population.

\section{Introduction}

The innovative development of the agricultural sector is one of the important issues in the development of the economy of countries and regions. Decisions related to increasing the competitiveness of the agricultural industry at all levels of government are becoming important for entrepreneurs, manufacturers and farms, who must provide the population with high-quality environmentally friendly products, improving the living standards of the population, and the demand for agricultural products in the domestic and foreign markets.

Modern ideas about the development of an innovative economy, namely its systematization of terms, classification, are presented in scientific works of both foreign authors $[1,2,3,4]$, and in domestic studies. Authors like S.D. Ilyenkova, V.I. Kuznetsova, $\mathrm{S} . \mathrm{Yu}$. Yagudin is defined: "the specific content of innovation is manifested in a change [5] in the context of the economic crisis, which are defined and revealed in the form of severe sanctions, the introduction of an embargo on certain types of goods".Systemic problems generated by the developmental features of the Russian socio-economic system put forward a strategy for the development of the regional economy in the agricultural sector.

The innovative development of the agro-industrial complex of the Republic of Bashkortostan is currently supported by the government.It is worth noting that such development is one of the priority direction for the development of the region's economy.

\section{Basic areas of agricultural development in modern conditions}

In the context of tough international sanctions against Russia, the need to comply with the rules and regulations of the WTO should not be forgotten. It is essential in the formation of the mechanism of government support for the agricultural sector. Until 2016, for Russia, the level of established obligations did not require a reduction in subsidies, however, the changed situation may lead to a probable increase in subsequent volumes of funding for agricultural support. This may lead to the government intending to limit subsidies.

The problem of government support of the agro-industrial complex is put forward in the priority directions of the industry and their economic efficiency.Some authors determine that the stability of economic systems is characterized by the ability to maintain a certain level of development in any economic conditions: "at the same time, maintaining stability should not contradict economic growth.Sustainable development should be understood as the state of the economic system, characterized by positive dynamics of the main economic indicators of activity, ensured and determined by the presence of an innovative factor, adaptability to 
changes in the external and internal environment, and coordination of the interests of all participants in socio-economic relations"

Thus, the authors of Marina Anokhina, Rakhat Abdrakhmanov, Yelena Evgenevna Gridneva, Milton Arrieta-López, Nuray Romanovna Dzhalilova, Abel Meza-Godoy determine that to carry out calculations and justify the contentof the strategy, the authors used the software product "Intelligent generation of the best alternatives" ("IGLA"). The result of the study is the developed strategy for the management of agricultural territories competitiveness in Kazakhstan with a set of strategic goals and the best option for managerial impact, ensuring the formation of agricultural export potential of the region. The proposed version of the content of the strategy for managing the competitiveness of the agricultural territories of Kazakhstan can be used either as a system or as its separate elements in managing the development of agricultural business in the country and in developing strategic planning programs for he agro-industrial complex of the region. [7]. Food independence issues remain relevant to any country. The current events in international relations make this issue more urgent and dictate the need to develop and implement a food security policy in Kazakhstan, taking into account the prevailing realities and potential of agricultural territories. It is the competitive potential of these territories that determines the ability of the government to provide itself with food resources. In Kazakhstan, more than $80 \%$ of the territories are agricultural. At the same time, a significant part of them is in a crisis state. The relevance of the problems of agricultural territory development is also confirmed by the growing number of scientific studies on this topic, namely the works of V. Bautin et al. [8] , L. Bondarenko [9]. Studies on increasing the efficiency of using the resources involved in the agricultural production process are the main topic of research done by N. Nechaev [10], Guiomar, N., Godinho, S.[11], Guth and Smędzik-Ambroży et al. [12]. The works of O. Ikonnikova [13], A. Tarasova et al. [14], N. Logantsova [15], E. Andersen [16], etc. are dedicated to the development of a comprehensive typologization of rural territories.

It should be noted that the innovation process in real economic life has divide between the main stages of creating innovations and their commercialization. This is due to factors such as the cessation of budget funding for research, high investment risks, the lack of interaction between science and business, etc. There are divide between the main stages of the innovation process, which lead to a slowdown in the development of economic processes, loss of financial resources and economic relations.

\section{Problems of government policy in the agricultural complex and its efficiency on the development of innovative economy of the Republic of Bashkortostan}

Those reforms of a multilevel economy that began in the early 90s of the XX century have become obsolete. Many regions of Russia have switched to an industrial model for the development of the agro-industrial complex. This model was characterized by consistently high growth rates in relation to those regions that used a multistructure model, where the growth rate of agricultural development is much lower, although this model can offset negative natural and climatic factors. Also, the decrease in the rate of urbanization is important. It is leads to a reduction in the able-bodied rural population, inefficiencies in labor productivity and small agricultural enterprises. [17]. This often leads to bankruptcy of small agricultural enterprises. Therefore, the transition to an industrial model of economic development will increase the efficiency of agricultural production. Based on the strategic plan for the development of the agro-industrial complex of the Republic of Bashkortostan for 2016-2020, priority tasks are identified such as: to increase the volume of agricultural production to 230 billion rubles by 2020 , including at least 140 billion rubles in agricultural 
enterprises and peasant farms. or $60 \%$; to increase the level of profitability of agricultural production up to $20 \%$ by 2020 ; to increase labor productivity to 2 million rubles per employee by 2020 ; to increase the share of production in agricultural enterprises and peasant (farmer) enterprises up to $60 \%$. Let us consider how small businesses are developed and supported by the government and how they affect the economy of the region.

\subsection{Analysis of the development of small forms of management}

Implementation of the state program "Development of agriculture and regulation of agricultural products, raw materials and food markets in the Republic of Bashkortostan", which is aimed at ensuring the fulfillment of planned values for the production of commodity volumes of production of the main types of products.Promotion of the activities of small business forms of the Republic of Bashkortostan inwithin the framework of the implementation of the regional project and the BPH program allowed our republictake first place in Russia in the number of agricultural cooperatives created-16\% of new cooperatives are in our region. For the development of small businessalmost 1 billion rubles were allocated for the first time in the village. Based on the results of all the work created: 108 newagricultural consumer cooperatives; 129 new farms; 620new jobs; 33 farms and cooperatives updated equipment andpurchased equipment. At the end of 2019 between the Ministry of AgricultureThe Russian Federation and the Government of the Republic of Bashkortostan concluded 15 agreements and 32 additional subsidy agreements.

It was revealed that in 2018836 agricultural enterprises functioned in the region, of which 725 farms completed the year profitably, the amount of revenue amounted to about 44.7 billion rubles, net profit -6.6 billion rubles. So, in the republic, the census covered 1,065 agricultural organizations, 4,003 peasant farms, 461 individual entrepreneurs, 807.9 thousand personal subsidiary and other individual households of citizens and 2081 non-profit associations of citizens (household and gardening). According to statistics, compared with 2006, the number of agricultural organizations, peasant (farmer) households and non-profit associations of citizens decreased. [17].

At the end of 2019, the planned values for the production of commodity production volumes of the main types of products were met. At the end of 2019, gross agricultural output in all categories of farms amounted to 167.1 billion rubles (according to Bashkortostan), which is $102 \%$ of the level of the corresponding period last year (plan - 101.6\%). The index of crop production amounted to $104.2 \%$ (plan - 101.9\%), livestock - $100.3 \%$ (plan - 101.3\%).

If we consider the indices of the physical volume of agricultural production by categories of farms in the Republic of Bashkortostan, thanks to the work carried out by the Ministry of Agriculture of the Republic of Bashkortostan, the amount of K (F) X increases annually (Fig. $1)$.

\section{The number of $\mathrm{K}(\mathrm{F}) \mathrm{X}$ in the Republic of Bashkortostan for 2016-2018, units}

" years " quantity

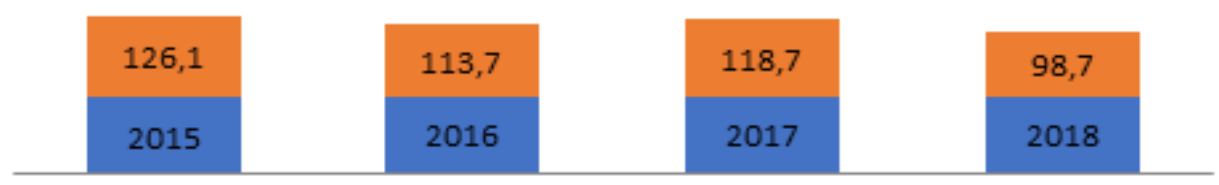

1

2

3

4 
Fig. 1 Volume indices of agricultural output by categories of farms (in comparable prices; as a percentage of the previous year) (in comparable prices; as a percentage of the previous year).

At the end of 2018, the total gross output of agricultural enterprises and peasant (farmer) farms amounted to $72,765.6$ million rubles, including 57,851 million rubles at agricultural enterprises (a share of 79.5\%) and in peasant (farmer) farms 14914 million rubles (share $20.5 \%$ ).

At the same time, the volume of government support for these categories of farms for the same period amounted to 6,351.6 million rubles, including 5322.1 million rubles. Agricultural enterprises and 1019.5 million rubles peasant (farmer) households. The share, respectively, was $84 \%$ and $16 \%$.

Thus, the volume of output per 1 ruble of government support for agricultural enterprises amounted to 8.41 rubles, for peasant farms - 9.58 rubles, which indicates a higher efficiency of government support for farms - by 13.9\%. Crop areas K (F) X increase annually (Fig. 2).

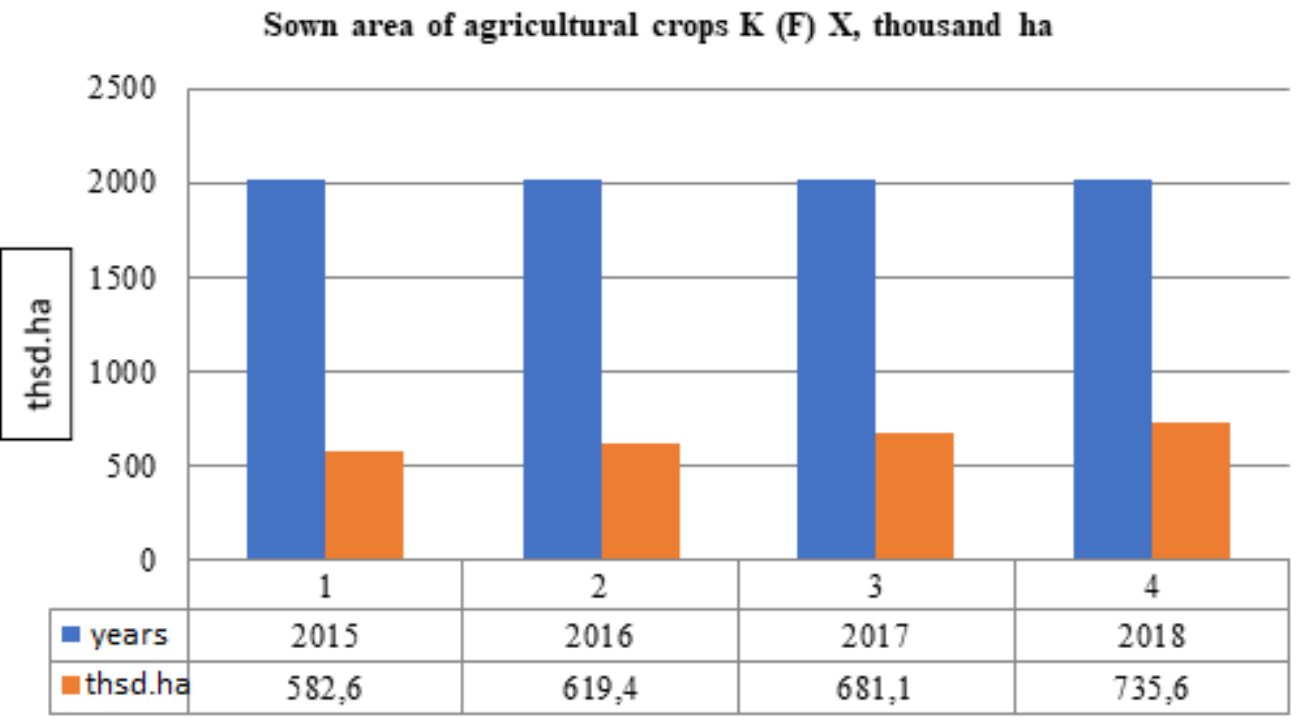

Fig. 2. Sown area of agricultural crops $K(F) X$, thousand ha

In 2018, the total number of cattle in farms amounted to 118.1 thousand cattle, which is $64 \%$ more than in 2017. In 2018, the trend maintained. According to operational data, as of May 1, 2018, the number of cattle in peasant farms amounted to 126.7 thousand heads of cattle( $94.6 \%$ by May $1,2015,11 \%$ of the livestock in farms of all categories), including 53.3 thousand cows. $(102.8 \%, 11.6 \%)$; pigs - 13 thousand heads of cattle $(95.6 \%, 2.8 \%)$, sheep and goats -93.8 thousandheads of cattle $(96.9 \%, 10.7 \%)$, horses -29 thousand heads of cattle $(108.3 \%, 23.5 \%)$, poultry -521.8 thousandheads of cattle( $97.9 \%, 5 \%)$.

However, the number of beef cattle in agricultural enterprises in recent years has tended to decrease. The source of beef production is rejected cows, overhaul of young dairy herds. Slaughter cattle obtained during dairy farming is not able to provide the necessary volumes of beef production and high quality of meat produced.

As of January 1, 2019, the Republic of Bashkortostan took 1st place among the subjects of the Russian Federation in the number of cattle and 10th in terms of livestock and poultry 
farming for slaughter in live weight. At the same time, in the Volga Federal District, cattle meat production accounted for $20 \%$ and $13 \%$.

The number of cattle by farm category in Bashkortostan is shown in table 1.

Table 1. The number of cattle by farm categories in the Republic of Bashkortostan, thousand heads of cattle

\begin{tabular}{|c|c|c|c|c|c|c|c|c|}
\hline \multirow{2}{*}{$\begin{array}{c}\text { Farm } \\
\text { category }\end{array}$} & \multicolumn{8}{|c|}{ Years } \\
\hline & 2011 & 2012 & 2013 & 2014 & 2015 & 2016 & 2017 & 2018 \\
\hline $\begin{array}{c}\text { Farms of all } \\
\text { categories }\end{array}$ & 1299,3 & 1248,2 & 1254,3 & 1240,1 & 1220,1 & 1110,8 & 1048,6 & 978,2 \\
\hline $\begin{array}{c}\text { Agricultural } \\
\text { organizations }\end{array}$ & 532,4 & 484,9 & 476,4 & 464,1 & 427,5 & 405,9 & 379,8 & 315,5 \\
\hline Households & 694,9 & 684,3 & 684,2 & 680,5 & 685,3 & 594,0 & 555,5 & 533,7 \\
\hline $\begin{array}{c}\text { Peasant(farmer) } \\
\text { households }\end{array}$ & 72,0 & 79,0 & 93,7 & 95,5 & 107,3 & 110,9 & 113,3 & 129 \\
\hline
\end{tabular}

Compiled by the author according to [18]

In 2018, in farms of all categories of the republic there were 978.2 thousandheads of cattle, including 315.5 thousand heads of cattle in agricultural enterprises, 533.7 thousand cattle in farms and 129 thousand heads of cattle in peasant (farmer) farms. Compared to the previous year, this indicator decreased by $4.9 \%$, and in agricultural organizations - by $9.1 \%$, in households - by $4.7 \%$, and in peasant (farmer) enterprises increased by $6 \%$.

At present, the beef cattle breeding of the republic is represented by Simmental, Hereford, limousine, Aberdeen-Angus, Kazakh white-headed breeds.

The structure of beef cattle breeding in the pedigree aspect is as follows: the share of Simmental cattle was 73\% (58.7 thousand cattle); Hereford - 5.6\% (4.5 thousand heads of cattle);Limousine - 4.5\% (3.6 thousand heads of cattle); Aberdeen-Angus crosses with Kazakh white-headed - 1.2\% (980 animals); crossbreeds of other breeds - 15.7\% (12.2 thousand heads of cattle).

As of January 1, 2019, the republic contained 80 thousand cattle of beef and pedigree cattle, including 28 thousand cattle of cows. At the same time, the share of specialized beef cattle was about $85 \%$. Produced for the slaughter of beef and cross in $2018-16.8$ thousand tons in live weight. The average daily increase in beef cattle of specialized breeds amounted to $832 \mathrm{~g}$, which is $42 \%$ more than the same indicator in the republic.

At present, there are three pedigree farms for breeding specialized beef cattle in Bashkortostan: Limousin breed - Yaroslavl shopping and entertainment center of the Duvan district (300 cattle), SAVA Agro Yaprik LLC of the Tuymazinsky district (1000 cattle), Hereford breed - SAVA Agro Usen. LLC "Tuymazinsky district" (800heads of cattle).

Particular importance is given to the development of digital services in the agricultural sector. So, the Ministry of Agriculture of Russia has signed an agreement on cooperation in developing the concept of the departmental project "Digital Agriculture". A project for operational monitoring of industry data and a geoanalytic field monitoring service have been implemented. The Republic is striving to achieve not only a growth in physical indicators, but also to ensure timely implementation of agricultural activities, climate control and work accounting, as well as reducing the shortage of qualified personnel. [20]

Table 2. PARAMETERS for achieving the planned values of target indicators and indicators of the state program (subprograms).

\begin{tabular}{|c|c|c|c|}
\hline № & Parameter name target benchmarks and indicators & $\begin{array}{c}\text { Quantity of } \\
\text { target }\end{array}$ & $\begin{array}{c}\text { Share, } \\
\text { percentage }\end{array}$ \\
\hline
\end{tabular}




\begin{tabular}{|c|l|c|c|}
\hline & & $\begin{array}{c}\text { benchmarks } \\
\text { and } \\
\text { indicators, } \\
\text { units }\end{array}$ & \\
\hline 1 & \multicolumn{1}{|c|}{2} & 3 & 4 \\
\hline 1 & $\begin{array}{l}\text { target benchmarks and indicators, planned values that have } \\
\text { been achieved, including: }\end{array}$ & 108 & 90,0 \\
\hline 1.1 & exceeded values of target benchmarks and indicators & 57 & 52,8 \\
\hline 2 & $\begin{array}{l}\text { targetbenchmarksandindicators, which planned values not } \\
\text { reached }\end{array}$ & 12 & 10,0 \\
\hline 3 & $\begin{array}{l}\text { targetbenchmarksandindicators, the values of which cannot } \\
\text { be determined at the end of the reporting period }\end{array}$ & - & - \\
\hline 4 & $\begin{array}{l}\text { Totaltargetbenchmarksandindicatorsof the government } \\
\text { program and subprograms }\end{array}$ & 120 & 100,0 \\
\hline 5 & $\begin{array}{l}\text { targetbenchmarksandindicatorsof the government program } \\
\text { and subprograms with the risk of failure }\end{array}$ & - & - \\
\hline
\end{tabular}

*Source [20]

In 2019, subsidies for the novice farmer program amounted to 161.2 million rubles. Applications were submitted - 399, 114 became participants. Regional programs like "Export of agricultural products to the Republic of Bashkortostan", "Creation of a support system for farmers and development of rural cooperation" are in force". Considerable work has been done regarding the technical modernization of production. For the first time, agrarians of the republic purchased machinery and equipment for a total amount of 6.5 billion rubles (which is 2.3 billion more than in 2018). The technical park was replenished with 200 combine harvesters, almost 400 tractors of various classes, more than 580 tillage and sowing machines and other equipment. At the end of 2019, between the Ministry of Agriculture of the Russian Federation and the Government of the Republic of Bashkortostan, 15 agreements and 32 additional agreements on the provision of subsidies were concluded.

\section{Conclusion}

Based on the analysis, the republic has great potential for increasing the number of livestock due to the additional placement of up to 300 thousand cattle, taking into account the area of forage crops, natural pastures and empty livestock complexes.

At the same time, special attention is paid to increasing the role and potential of small farms in the production of high-quality beef, increasing the number of beef cattle and crossing animals based on the development of family farms based on peasant (farmer) farms. This will greatly contribute to the development of abandoned and degraded hayfields and pastures, a partial decrease in unemployment, an improvement in the demographic situation in rural areas and an improvement in the quality of life of the rural population.

In the republic, it is necessary to increase the investment attractiveness of the beef cattle breeding industry and provide conditions for the implementation of promising investment projects for the construction of fattening and meat farms, which will increase the production of high-quality competitive beef.This would allow to maximize the load of existing processing facilities, as well as create the prerequisites for the construction of new ones. Production of high-quality meat raw materials, expanding the assortment and strengthening the position of brands of meat products produced in Bashkortostan will increase the export potential of the republic, as well as increase the export of products to regions adjacent to the republic.

The main obstacles to the successful realization of the existing potential for the sustainable development of competitive beef cattle breeding are the small number of beef cattle, the insufficient level of technical and technological equipment of the industry, the 
unsatisfactory condition and use of natural fodder land, poor forage for feeding, low potential for livestock productivity and low economic motivation of agricultural producers to fattening. cattle and beef production.

The lack of economic motivation is the main obstacle to the realization of the opportunities available in the republic for the accelerated development of beef cattle breeding.

The unprofitable industry depends on many reasons, but to a certain extent this is due to low livestock performance:

- calves yield is less than $80 \%$ instead of $85-90 \%$ required for cost-effective beef cattle breeding;

-weights of young fattening do not exceed 400 - $500 \mathrm{~g}$ instead of the necessary 1000 $1200 \mathrm{~g}$;

- the average live weight of young animals after weaning at the age of 7 - 8 months - no more than 170 - $200 \mathrm{~kg}$ instead of $240 \mathrm{~kg}$ and more.

-the onset of dangerous agrometeorological phenomena during the sowing period, difficulties in selling grain at prices that compensate for production costs, the lack of a republic in the list of regions with preferential grain transportation by rail, has led farms of the Republic of Bashkortostan to review the structure of sown areas in the direction of expanding the area of high-margin industrial crops (rapeseed, camelina, flax, mustard, etc.) having stable high demand and high selling prices.

An important condition for the successful development of specialized meat cattle breeding is the formation of a market for high-quality beef. The agricultural enterprises involved in beef cattle breeding and capable of supplying a large number of young beef cattle to industrial feedlots are interested in this.

The Republic of Bashkortostan has all the necessary factors for the formation of a large and effectively functioning industry of specialized meat cattle breeding in order to provide consumers with high-quality beef, such as:

4.5 million hectares of forage land, including 1.1 million hectares of hayfields, 2.3 million hectares of pastures and 1.1 million fodder crops on arable land; low-cost extensive pasture technology of meat cattle breeding, tested in the conditions of Bashkortostan; resources for breeding and keeping beef cattle with livestock up to 100 thousand heads or more.

\section{References}

1. C. Antonelli, The Economics of Innovation, New Technologies, and Structural Change, 210 (London: Routledge, 2003)

2. R.D. Atkinson, S.J. Ezell, Innovation Economics. The Race for Global Advantage, 440 (New Haven: Yale University Press, 2012)

3. G. Cecere, Journal of Technology Transfer, 40, 185-197 (2015)

4. J. Squalli, K. Wilson, Intelligence, 46, 250-257 (2014)

5. S.D. Ilyenkova, V.I. Kuznetsov, S.Yu. Yagudin, Innovation Management. Educationalmethodical complex, 192 (M.: MESI, 2009)

6. L.N. Orlova, S.A. Ostroukhov, Innovative activity in the system of sustainable development of sports organizations, VI International Scientific and Practical Forum Innovative Development of the Russian Economy, 472 (Moscow State University of Economics, Statistics and Informatics - M., 2013)

7. M. Anokhina, R. Abdrakhmanov, Y.E. Gridneva, M. Arrieta-López, N.R. Dzhalilova, A. Meza-Godoy, Entrepreneurship and sustainability issues, 1921-1936 (2020)

8. V.M. Bautin, V.V. Kozlov, A.V. Merzlov, Sustainable rural development: issues of strategy and tactics (Moscow: FGNU "Rosinformagrotekh", 2004)

9. L. Bondarenko, AIC: economy, management, 71-82 (2015) 
10. V. Nechaev, AIC: economy, management, 43-53 (2016)

11. N. Guiomar, S. Godinho, T. Pinto-Correia, M. Almeida, F. Bartolini, P. Bezák, M. Biró, H. Bjørkhaug, Š. Bojnec, G. Brunori, et al., Land Use Policy, 784-798 (2018)

12. M. Guth, K. Smędzik-Ambroży, Economic Research-Ekonomska Istraživanja (2019) https://doi.org/10.1080/1331677X.2019.15852702019

13. O. V. Konnikova, Agriculture, forest and water management, 11 (2014). URL: http://agro.snauka.ru/2014/11/1658

14. A.N. Tarasov, N.I. Antonova, et al. Typology of rural areas based on economic diversification: a monograph (Rostov-on-Don: Azov Pechat, 2016)

15. N.V. Logantsova, Agricultural Economics of Russia, 9, 63-69 (2013)

16. E. Andersen, European Journal of Agronomy, 82-291 (2017)

17. Agriculture of Bashkiria - what has changed over 10 years. URL: http://www.bashinform.ru/news/1142735-selskoe-khozyaystvo-bashkirii-chtoizmenilos-za-10-let/

18. Agriculture, hunting and forestry. The territorial body of the Federal State Statistics Service for the Republic of Bashkortostan. URL: https://bashstat.gks.ru/folder/26015. The Government of the Republic of Bashkortostan by resolution of June 17, 2019 № 353 On approval of the comprehensive program Development of beef cattle breeding in the Republic of Bashkortostan. URL: http://docs.cntd.ru/document/553377658

19. R.N. Galikaev, Bulletin BIST. Series Economics, 1 (42), 63-71, (2019)

20. Explanatory note to the progress report and on assessing the effectiveness of government program Development of agriculture and regulation of agricultural products and food markets in the Republic of Bashkortostan for 2019. URL: https://agriculture.bashkortostan.ru/documents/reports/277392 